\title{
Functionalized Caprolactone-Polyethylene Glycol Based Thermo- Responsive Hydrogels of Silibinin for the Treatment of Malignant Melanoma
}

\begin{abstract}
Behzad Sharif Makhmalzadeh ${ }^{1,2}$, Ommoleila Molavi ${ }^{1,3}$, Mohammad Reza Vakili ${ }^{1}$, Hai-Feng Zhang ${ }^{4}$, Amir Solimani ${ }^{1}$, Hoda Soleymani Abyaneh $^{1}$, Raimar Loebenberg ${ }^{1}$, Raymond Lai $^{4}$, Afsaneh Lavasanifar ${ }^{1}$

${ }^{1}$ Faculty of Pharmacy and Pharmaceutical Science, University of Alberta, Edmonton T6G 2E1, Canada. ${ }^{2}$ Nanotechnology research center, Ahvaz Jundishapur University of Medical Sciences, Ahvaz, Iran. ${ }^{3}$ Biotechnology Research Center, Tabriz University of Medical Sciences, Tabriz, Iran. ${ }^{4}$ Department of Pathology and Laboratory Medicine, University of Alberta, Edmonton T6G 2E1, Canada
\end{abstract}

Received, December 22, 2017; Revised, February 9, 2018; Accepted, April 10, 2018; Published, April 24, 2018.

\begin{abstract}
Purpose: Silibinin, is a natural compound, which has shown anticancer activity in various malignancies. In this study, we evaluated the anticancer effects of silibinin in B16-F10 melanoma cells and developed a novel thermoresponsive hydrogel for local delivery of this compound. Method: A thermoresponsive hydrogel loaded with silibinin was prepared using triblock copolymers of poly[( $\alpha$-benzyl carboxylate- $\varepsilon$-caprolactone)-co-( $\alpha$-carboxyl- $\varepsilon$-caprolactone $)]_{\mathrm{ran}}-b$-PEG- $b$ - $[(\alpha$-benzyl carboxylate- $\varepsilon$-caprolactone $)$ -co-( $\alpha$-carboxyl- $\varepsilon$-caprolactone $)]_{\text {ran }}$ (PCBCL- $b$-PEG- $b$-PCBCL), namely PolyGel ${ }^{\mathrm{TM}}$, and compared with a Pluronic F-127 formulation of silibinin. Sol-gel transition temperature of hydrogels was measured by inverse flow method and modulated differential scanning calorimetry (MDSC). Silibinin loading efficiency was measured by HPLC. The MTT and clonogenic assays were used to assess the cytotoxicity and anti-proliferative effects of silibinin on B16-F10 melanoma cells. Flow cytotmetry was used to quantify the induced level of apoptosis and measure the intracellular level of activated STAT3 (pSTAT3) following silibinin treatment in B16.F10 cells. The effects of silibinin on the activation of oncogenic proteins were also evaluated by western blot. Results: Silibinin inhibited cell proliferation $\left(\mathrm{IC}_{50}=67 \mu \mathrm{M}\right)$, provoked cell cycle arrest, induced apoptosis, suppressed key oncogenic pathways (i.e STAT3 and MEK/ERK), and enhanced the cytotoxic effects of doxorubicin in B16-F10 cells. Both PolyGel ${ }^{\mathrm{TM}}$ and Pluronic F-127 hydrogels were effective in loading silibinin. A lower drug release pattern within $24 \mathrm{~h}$, fitting first- order release kinetics, was observed for the release of silibinin from both gels compared to free drug. PolyGel ${ }^{\mathrm{TM}}$ demonstrated enhanced percutaneous absorption of silibinin through increasing mouse skin intracellular lipid fluidity as documented by DSC of skin following PolyGel $^{\mathrm{TM}}$ use. Silibinin loaded in PolyGel ${ }^{\mathrm{TM}}$ inhibited the growth of B16-F10 cells $\left(\mathrm{IC}_{50}=30 \mu \mathrm{M}\right)$ and effectively suppressed pSTAT3 activity in B16-F10 cells at $10 \mu \mathrm{M}$. Conclusion: Our results imply a great potential for PolyGel ${ }^{\mathrm{TM}}$ formulations of silibinin for local treatment of malignant melanoma.
\end{abstract}

This article is open to POST-PUBLICATION REVIEW. Registered readers (see "For Readers") may comment by clicking on ABSTRACT on the issue's content page.

\section{INTRODUCTION}

Silibinin is one of the most abundant and active components of silymarin, a polyphenolic flavonoid isolated from seeds of the milk thistle, i.e., Silybum marianum. Silymarin is primarily used as a traditional medicine in oral form to treat liver disorders (such as hepatitis and cirrhosis) and to protect liver against chemical and environmental toxins (1). In addition to these effects, silymarin and its components have been shown to act as a protective agent against photocarcinogenesis; UV-B and chemical tumor promoter-induced skin inflammation and UV-A-induced damage to human keratinocytes (2-6). Besides its preventive effect, several recent data point to the therapeutic value of silymarin and its components in cancer. An increasing number of studies report that silibinin inhibits multiple oncogenic signaling pathways and exert potent growth inhibitory effects in different types of cancer (7-10).

Corresponding Author: Dr. Afsaneh Lavasanifar, Faculty of Pharmacy and Pharmaceutical Science, Katz Group Center for Pharmacy and Health research, University of Alberta, Edmonton T6G 2E1, Canada; Email Address: afsaneh@ualberta.ca 
Previous studies have demonstrated strong therapeutic activity of silibinin in inhibiting the migratory and invasive characteristics of cancer cells pinpointing to the potential of this drug in the treatment of metastatic malignancies such as malignant melanoma (11-15). One of the most important cancer oncogenic pathways suppressed by silibinin is signal transducer and activator 3 (STAT3) $(10,16,17)$. STAT3 is found constitutively active in many types of human malignancies including malignant melanoma and plays a key role in cancer progression (18). In addition, consecutive expression of p-STAT3 has been also indicated as a therapeutic target in inflammatory conditions affecting skin such as psoriasis. Therefore, silibinin is considered a promising drug for treatment of cancer and some skin inflammatory disease such as psoriasis.

Unfortunately, plasma levels of silibinin following oral administration of silymarin are generally lower than concentrations needed for its therapeutic effects. This is mainly due to poor absorption and rapid metabolism of silibinin following oral administration $(19,20)$. It is; therefore, not surprising that the silibinin levels reaching skin after oral administration of silymarin are well below its therapeutic threshold, as well. Development of effective formulations that can provide steady and high skin levels of silibinin can have several potential therapeutic applications.

Here, we first studied the suppressive effects of silibinin on the cell growth and the key oncogenic pathways in B16-F10 melanoma cells. We then assessed the potential of a thermoresponsive hydrogels based on PEG and functionalized poly $(\varepsilon-$ caprolactone) developed by our research group (namely PolyGel ${ }^{\mathrm{TM}}$ ) for silibinin delivery through skin compared to that of Pluronic ${ }^{\circledR}$ F-127, a commercially available hydrogel extensively used for topical drug administration (Scheme 1). Both Pluronic $^{\circledR}$ F-127 and PolyGel ${ }^{\mathrm{TM}}$ are thermoreversible hydrogels with critical gelation temperatures (CGT)s around 20 and $35^{\circ} \mathrm{C}$ above their corresponding critical gelation concentrations (CGC). The advantage of PolyGel ${ }^{\mathrm{TM}}$ over Pluronic ${ }^{\circledR}$ is its much lower CGC (10 versus $25 \mathrm{w} / \mathrm{w} \%$ ), which will reduce the required amount of gel forming material for topical or subcutaneous administration (21). Moreover, the potential for sustained drug release, degradability as well as $\mathrm{pH}$ sensitivity of PolyGel ${ }^{\mathrm{TM}}$ may make this biomaterial more appealing for depot or stimulus responsive drug release through other routes of administration.

\section{MATERIALS AND METHODS}

\section{MATERIAL}

Silibinin, Pluronic ${ }^{\circledR}$ F-127, dimethyl sulfoxide (DMSO), 3-(4,5-dimethylthiazol-2-yl)-2,5-diphenyl tetrazolium bromide (MTT), dihydroxy poly(ethylene glycol) (PEG, MW=1450 Da), palladium, $10 \%$ on activated charcoal were purchased from Sigma-Aldrich (St-Louis, MO). Fetal bovine serum (FBS) was obtained from Hyclon (Logan UT). Dulbecco modified eagle, RPMI-1640, L-glutamine was purchased from Gibco-BRL (Burlington, Ontario, Canada). $\alpha$ Benzyl carboxylate- $\varepsilon$-caprolactone (BCL) was synthesis by Alberta Research Chemicals Inc (ARCI), Edmonton, Canada. All solvents used were of analytical grade and obtained from SigmaAldrich (St-Louis, $\mathrm{MO}$ ). $\mathrm{CDCl}_{3}$ was used as solvent to run NMR spectra. NMR spectra were recorded by a $600 \mathrm{MHz}$ Bruker Avance III instrument. All the first and secondary antibodies for western blotting were purchased from Cell Signaling Technologies, Danvers, MA.

\section{Cell line and animals used in the study}

B16-F10 melanoma cell line from ATCC was grown in Dulbecco's modified Eagle's medium (DMEM) supplemented with $10 \% \mathrm{FBS}$ at $37^{\circ} \mathrm{C}$ and humidified $5 \% \mathrm{CO}_{2}$. Mice skin was obtained from 4-5 weeks-old C57 mice (purchased from Charles River).

\section{Cell toxicity assay}

B16-F10 melanoma cells were plated at the density of 5000 cells per well in a 96 well-plate. After overnight incubation, the cells were treated with silibinin formulations at different concentrations. In silibinin-doxorubicin combinational therapy studies, the cells were treated with silibinin at $125 \mu \mathrm{M}$ concentration along with $18 \mu \mathrm{M}$ of doxorubicin. Monotherapy groups including the cells treated with either silibinin or doxorubicin at the same concentrations as combinational therapy were used for comparison. 


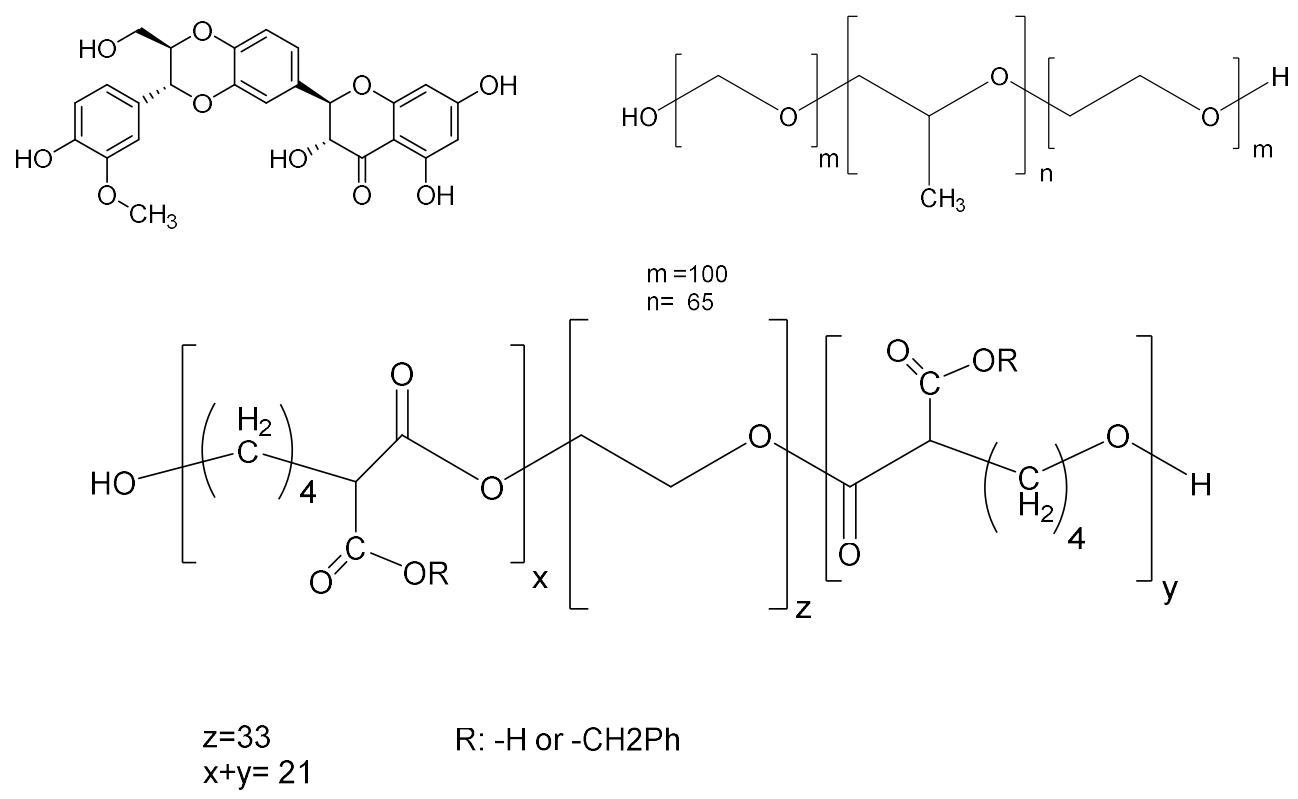

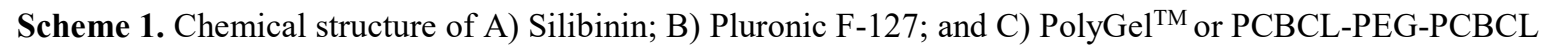

In cell cytotoxicity assays, control groups were treated with either $2 \%$ DMSO or hydrogels without silibinin. Cell viability was measured with MTT assay 24 and 48 hours after treatment and normalized to the cell viability of control group (22). To evaluate synergic versus additive effects of silibinin and doxorubicin combinational therapy, CompuSyn software was applied to generate the dose-effect curves for single agents and their combinations using the data obtained from MTT assays. The combination index (CI) values for each dose and the corresponding effect level, referred to as the fraction affected $\left(\mathrm{f}_{\mathrm{a}}\right.$; the fraction of cells inhibited after the drug exposure, e.g. 0.5 when cell growth is inhibited by $50 \%$ ), were calculated. The CI value at $f_{a}=0.5$ has been reported for the combinational therapy in the present research work. The combination index offers a quantitative definition for an additive effect $(\mathrm{CI}=1)$, synergism $(\mathrm{CI}<1)$, and antagonism $(\mathrm{CI}>1)$ in drug combinations.

\section{Apoptosis Assays}

To examine apoptosis in B16-F10 cells treated with silibinin, the cells were counted after $48 \mathrm{~h}$ incubation with silibinin and stained with annexinV/propidium iodide (PI) according to the manufacturer's instructions (BD Biosciences, Mississauga, ON). The samples were then analyzed on a Becton Dickinson (Franklin Lke, NJ, USA) FACSCalibur flow cytometer. To assess cell cycle in B16-F10 cells treated with silibinin, the cells were stained with PI and cell-cycle analysis was performed by flow cytometry. In brief, cells were fixed with ice-cold $70 \%$ ethanol 48 hours after treatment. These cells were then subjected to RNase treatment and PI staining. After $30 \mathrm{~min}$ incubation with PI at room temperature, the cells were washed and immediately analyzed on a Becton Dickinson (Franklin Lke, NJ, USA) FACSCalibur flow cytometer. Data acquisition was gated to exclude cell doublets, and the cell-cycle phase distribution was determined using the CellQuest program (20 000 events were counted). The experiments were performed in triplicate and repeated on two separately initiated cultures.

\section{Western blot}

Western blot was performed as described previously (23). All antibodies were diluted in 5\% 
bovine serum albumin (BSA) in Tris buffered saline and $0.1 \%$ Tween-20 (TBST). The expression of $\beta$ actin served as the loading control for all Western blots.

\section{Plasmid Constructs and Cell Transfection}

The constitutively active form of STAT3 (STAT3C) was a pRc/CMV-Stat3C plasmid that was acquired as a gift from Dr. Jacqueline Bromberg (24). Constitutively active form of MEK1 (HA-CA-MEK) was a gift from Dr Nathalie Rivard (Université de Sherbrooke) (25). The transient transfection of B16-F10 cells with these two plasmids were performed with the Lipofectamine 2000 reagent (Life Technologies, Burlington, ON, Canada). The cells were transfected with either STAT3C or CA-MEK, incubated for 24 hours, and then they were treated with silibinin at different concentrations. After $24 \mathrm{~h}$ incubation, the cell viability was assessed by MTT. To show that the transfection is stable during the experiment, the levels of constitutively active STAT3 (p-STAT3) and ERK (p-ERK) were evaluated in the cells transfected with the corresponding constructs for 24 hours and then treated with silibinin at the highest concentration in each experiment for $24 \mathrm{hs}$.

\section{Clonogenic assay}

To assess the anti-proliferative effects of silibinin in B16-F10 cells, the cells were seeded with a density of 250 cells/well in a 12-well plate. After overnight growth, the cells were treated with different concentrations of silibinin and incubated for $24 \mathrm{~h}$. After incubation, the media was changed with drugfree media and the cells were cultured for another eight days before staining. For staining, the cells were washed with PBS three times. Then, cells were fixed in cold $100 \%$ methanol for $5 \mathrm{~min}$ and stained with crystal violet for $20 \mathrm{~min}$.

\section{Evaluation of pSTAT3 level by flow cytometry}

Intracellular staining of pSTAT3 in B16-F10 cell was done with PE labeled-anti pSTAT3 antibody. B16-F10 cells treated with silbinin formulations or control vehicles were collected and washed twice with PBS and then fixed by PBS/Para formaldehyde fixation solution at $4{ }^{\circ} \mathrm{C}$ for $30 \mathrm{~min}$. The cells were then permeabilized by ice-cold $100 \%$ methanol, incubated $30 \mathrm{~min}$ at $-20^{\circ} \mathrm{C}$, and stained with PE labeled anti p-STAT3 antibody for $60 \mathrm{~min}$ at room temperature. After 3 washes with incubation buffer, samples were collected on falcon tube and analyzed by flow cytometry (FACSCantoII Cytometer, BD FACSDiva 6.1.3).

\section{Synthesis of triblock copolymer}

Triblock copolymer was synthesized using a twostep synthesis procedure as reported before (26). Briefly, a mixture of dihydroxy PEG and $\alpha$ benzylcarboxylate- $\varepsilon$-caprolactone (BCL) was transferred to vacuum oven $160^{\circ} \mathrm{C}$ for $11 \mathrm{~h}$. The product, i.e., poly $(\alpha$-benzyl carboxylate- $\varepsilon-$ caprolactone) $-b$-PEG- $b$-poly ( $\alpha$-benzyl carboxylate- $\varepsilon$-caprolactone) (PBCL- $b$-PEG- $b$ PBCL) was purified by dissolving it in dichloromethane and precipitation in hexane followed by repeated washing with hexane. The PBCL- $b$-PEG- $b$-PBCL block copolymer was then reduced with continuous hydrogenation in the presence of palladium on activated charcoal $(10 \%$ by weight of the polymer) leading to the synthesis of poly[( $\alpha$-benzyl carboxylate- $\varepsilon$-caprolactone $)$ - co( $\alpha$-carboxyl-e-caprolactone $)]_{\text {ran }}-b-\mathrm{PEG}-b-[(\alpha-$ benzyl carboxylate- $\varepsilon$-caprolactone)-co-( $\alpha$-carboxyl$\varepsilon$-caprolactone) $]_{\mathrm{ran}} \quad$ (PCBCL- $b$-PEG- $b$-PCBCL). Tetrahydrofuran (THF) was used as solvent. The degree of reduction was controlled by hydrogen flow rate and reaction time. THF was then evaporated and the product was dissolved in dichloromethane and precipitated in hexane three times. This block copolymer is referred as PolyGel $^{\mathrm{TM}}$ throughout the manuscript.

\section{Critical micelle concentration (CMC) measurement}

The CMC of the polymeric solutions in Tris buffer (pH 7.4) was estimated by dynamic light scattering (DLS) using Malvern Nano-ZS90 Zeta-sizer (Malvern instruments Ltd., Malvern, U.K). Below the $\mathrm{CMC}$, solution demonstrates low intensity of scattered light. At $\mathrm{CMC}$, sharp increase in the scattered intensity/ kcps was observed. The CMC was calculated with extrapolation of the intensityconcentration curve (27).

\section{Preparation of gels and silibinin loading}

The cold method as reported by Soga et al (28) was used for gel preparation from PolyGel $^{\mathrm{TM}}$ and Pluronic $^{\circledR}$ solutions in Tris buffer. Different amounts of polymers were added to $10 \mathrm{~mL}$ Tris buffer $(\mathrm{pH}=7.4)$ in flat-bottomed screw-capped 
glass vial and mixed for $24 \mathrm{hs}$ at $4^{\circ} \mathrm{C}$ until a clear solution was obtained. Defined amounts of silibinin was added to clear solution of polymers and mixed with magnetic stirrer for $8 \mathrm{~h}$ at $4^{\circ} \mathrm{C}$ (silibinin is stable at low temperatures).

Determination of the sol-gel transition temperature by tube inversion method

Different amounts of PolyGel ${ }^{\mathrm{TM}}$ and Pluronic ${ }^{\circledR}$ were dissolved in Tris-buffer $(\mathrm{pH}=7.4)$ and immersed in water bath. The temperature of water bath was increased by $1{ }^{\circ} \mathrm{C}$ every $5 \mathrm{~min}$ from $25^{\circ} \mathrm{C}$ to $60^{\circ} \mathrm{C}$. The phase transition was evaluated by inverting the tube. The temperature, at which the polymer solution did not show any flow for 1 min, was recorded as sol-gel transition temperature.

\section{Sol-gel transition temperature by modulated differential scanning calorimetry (MDSC)}

Aqueous solutions of Pluronic ${ }^{\circledR}$ F-127 and PolyGel $^{\mathrm{TM}}$ at different concentrations were prepared in Tris buffer $(\mathrm{pH}=7.4)$. Defined amount of each sample was hermetically sealed in an aluminum pan. Thermal analysis was done with a Q Series ${ }^{\mathrm{TM}}$ 2000 modulated differential scanning calorimeter. Samples were first heated to $60^{\circ} \mathrm{C}$ and kept at this temperature for $5 \mathrm{~min}$ to remove their thermal history. Then the temperature was reduced to $0^{\circ} \mathrm{C}$ at a rate of $5^{\circ} \mathrm{C} / \mathrm{min}$. Samples were kept at this temperature for $5 \mathrm{~min}$ and temperature was increased to $60^{\circ} \mathrm{C}$ at the same rate. Modulated mode was applied with an amplitude of $+0.5^{\circ} \mathrm{C}$ in $60 \mathrm{~s}$ and a ramping of $1{ }^{\circ} \mathrm{C}$ per min. All experiments were performed under nitrogen gas using a pan filled with water as reference.

\section{In vitro release studies}

Drug release profiles for silibinin loaded in Pluronic ${ }^{\circledR}$ F-127 gel (at $27 \% \mathrm{w} / \mathrm{w}$ ) and PolyGel ${ }^{\mathrm{TM}}$ (at $15 \% \mathrm{w} / \mathrm{w}$ ) at silibinin concentration of 50 $\mu \mathrm{g} / \mathrm{mL}$ were studied using dialysis method. Free silibinin dissolved in Tris buffer at the same concentration was used as control. For this, $1 \mathrm{~mL}$ solution of drug loaded gel or free drug was placed in a pre-swollen dialysis bag of 12000-14000 Da, molecular weight cutoff (Spectra/Por dialysis membrane; spectrum Lab, Canada) and immersed into $10 \mathrm{~mL}$ of Tris-buffer $(\mathrm{pH}=7.4)$ containing $0.1 \%$ tween $80(\mathrm{w} / \mathrm{v})$ as release medium. A flat-bottomed glass vial containing the dialysis bag and the release medium was shaken in a thermostatic shaker at $37^{\circ}$
$\mathrm{C}$ at $50 \mathrm{rpm}$. Samples were taken at predetermined time interval over $24 \mathrm{~h}$ from the release media. Concentration of released silibinin was determined by HPLC with C18 column (Waters; WAT027324) (29) using UV detector at $288 \mathrm{~nm}$ and methanol/water (80/20) as mobile phase at a flow rate of $1 \mathrm{~mL} / \mathrm{min}$. The difference in the in vitro release profiles was assessed by calculating the similarity factor, $f_{2}$ according to the following equation (30):

$f_{2}=50 \times \log \left(\left[1+\frac{1}{n} \sum_{i=1}^{n}\left(R_{i}-T_{i}\right)^{2}\right]^{-0.5} \times 100\right)$

$\mathrm{Ri}$ and $\mathrm{Ti}$ represent the percent released at time $\mathrm{i}$ from the formulations, labeled as reference (R) and tested (T). Two release profiles were considered to be equivalent when their $f_{2}$ value was within the range of 50-100.

\section{Ex vivo skin permeation and retention experiment}

Franz diffusion cells with diffusion area of $2.7 \mathrm{~cm}^{2}$ were used for this experiment. The mouse skin was mounted between donor and receiver compartments with stratum corneum facing the donor phase. $2 \mathrm{~mL}$ of silibinin loaded hydrogel $(50 \mu \mathrm{g} / \mathrm{mL})$ and silibinin in Tris buffer $(50 \mu \mathrm{g} / \mathrm{mL})$ were applied on the donor side of the skin. Receiver compartment was filled with $12 \mathrm{~mL}$ of phosphate buffer $(\mathrm{pH}=$ 7.0). Temperature was set at $32{ }^{\circ} \mathrm{C}$. Samples were taken at $0.5,1,2,3,4,5,6,24,48 \mathrm{~h}$ from the donor side and analyzed by HPLC.

\section{DSC of skin after PolyGel ${ }^{\mathrm{TM}}$ treatment}

Thermogram of skin after $28 \mathrm{~h}$ treatment with hydrogels (without drug) in comparison to skin without any treatment were recorded using DSC. Samples were heated from 0 to $50^{\circ} \mathrm{C}$ and held for 5 min, then cooled back to $0^{\circ} \mathrm{C}$ and again heated to $120^{\circ} \mathrm{C}$ at $5^{\circ} \mathrm{C} / \mathrm{min}$ rate. An empty pan was used as reference.

\section{STATISTICAL ANALYSIS}

Data were presented as the mean of three experiments and compared by one way analysis of variances (ANOVA), followed by Tukey's post hoc tests. P-value $<0.05$ was accepted as the level of significance. Data analysis was done with Microsoft Excel and Minitab 16. $\mathrm{P}<0.05$ is denoted by * and $\mathrm{p}<0.01$ is denoted by $* *$ in the figures. 


\section{RESULTS}

\section{The cell growth inhibitory effects of silibinin in} B16-F10 melanoma cells

We first evaluated the anticancer effects of silibinin on melanoma cells, in vitro. As it has been shown in Figure 1A, silibinin inhibited the growth of B16F10 melanoma cell line with an average $\mathrm{IC}_{50}$ of 67 $\mu \mathrm{M}$. To assess the anti-proliferative effect of silibinin on melanoma cells, the cells were subjected to clonogenic assay after $24 \mathrm{~h}$ incubation with three different concentrations of silibinin. The images of clonogenic assay shown in Figure 1B, indicate a significant decrease in the number of colonies following treatment with silibinin. Annexin V/PI analysis of the B16-F10 cells treated with silibinin at $150 \mu \mathrm{M}$ concentration for $48 \mathrm{hs}$ revealed more than \% 50 increase in the number of late apoptotic Annexin $\mathrm{V}^{+} / \mathrm{PI}^{+}$cells (Figure 1C). The anti-proliferative activity of silibinin was associated with an increase in the fraction of cells in the sub $\mathrm{G}_{0 / 1}$ phase determined by PI staining. As it is shown in Figure 1D, the fraction of cell in sub $\mathrm{G}_{0 / 1}$ phase increased from $1.7 \%$ in untreated cells to $29.7 \%$ in the cells treated with silibinin for $48 \mathrm{~h}$.

Previous studies have shown that combination of silibinin with chemotherapeutic agents results in enhanced anticancer effects in different types of human malignancies (31). Here, B16-F10 cells were treated with silibinin and/or doxorubicin. As it has been summarized in Figure 1E, treatment of B16F10 cells with doxorubicin $(18 \mathrm{nM})$ in combination with silibinin $(125 \mu \mathrm{M})$ resulted in a significant decrease in cell viability as compared with the cells treated with either silibinin or doxorubicin alone. The percentage of viable cells decreased from $36 \%$ in the cells treated with doxorubicin alone to $9 \%$ in the cells treated with doxorubicin in combination with silibinin for 48 hours. CI for silibinin and doxorubicin combinational therapy was found to be 1 which indicates that these two compounds induce an additive cytotoxic effect in B16 melanoma cells.

\section{Suppressive effects of silibinin on key oncogenic proteins in B16-F10 melanoma cells}

STAT3, ERK, and Akt are found constitutively active in many melanoma cell lines and primary tumors promoting tumor progression through induction of cell proliferation and prevention of cell apoptosis (32-35). In an attempt to find out the molecular targets of silibinin in B16-F10 melanoma cells and study the mechanism by which this agent exerts its anticancer effects, we measured changes in the level of active (phosphorylated) form of STAT3, ERK, and Akt as well as their unphosphorylated form following treatment with silibinin. As illustrated in Figure 2A, treatment of B16-F10 with silibinin at varying concentrations resulted in a significant decrease in phosphoSTAT3 (pSTAT3), phospho-Akt (pAkt) and phospho-ERK (pERK), all of which are known to be important onco-proteins promoting cell growth and survival. The decrease in the activity of these survival pathways was correlated with the suppression of $\mathrm{Bcl} 2$, an important anti-apoptotic protein. Silibinin also suppressed Src which is known to be an important oncogenic protein in various human malignancies including melanoma (36-39). The induction of apoptosis in B16-F10 melanoma cells was also supported by an increase in the level of cleaved caspease 3 and cleaved PARP, $48 \mathrm{~h}$ following treatment with silibinin.

To determine whether suppression of STAT3 and ERK pathways contribute to the growth inhibitory effects of silibinin in B16-F10 melanoma cells, B16-F10 cells were transfected with either STAT3C (a constitutive active form of STAT3) or CA-MEK (a constitutive active form of ERK) $24 \mathrm{hs}$ prior to treatment with silibinin. Western blot analysis showed the activation of STAT3 and ERK in the cells transfected with the corresponding construct during the study period (supplementary data Figure S1). As it has been shown in Figure 2B, constitutive activation of STAT3 (using STAT3C) in B16-F10 cells treated with silibinin at two different concentrations resulted in a statistically significant increase in cell viability as compared to the control group transfected with the empty vehicle. Likewise, transfection of B16-F10 cell with CA-MEK prior to treatment with silibinin significantly increased cell viability in test group as compared to the cells transfected with empty vehicle (Figure 2C).

We also performed a clonogenic assay to confirm STAT3-mediated suppressive effects of silibinin on growth and proliferative activity of B16-F10 cells. B16-F10 cells were transfected with either empty vector or STAT3C then they were treated with silibinin at the concentration of $25 \mu \mathrm{M}$. After 24 hs, cells were collected and subjected to the clonogenic assay. As it has been shown in 
A

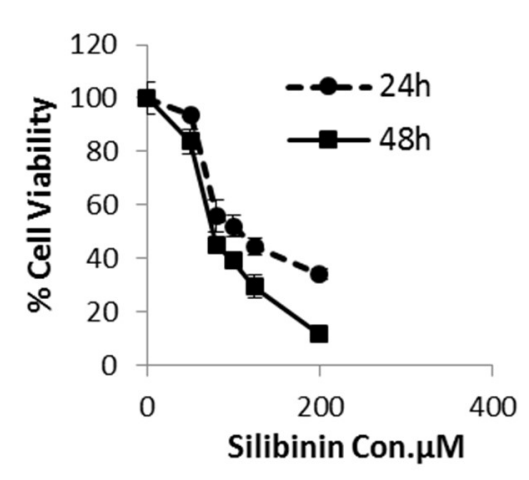

B
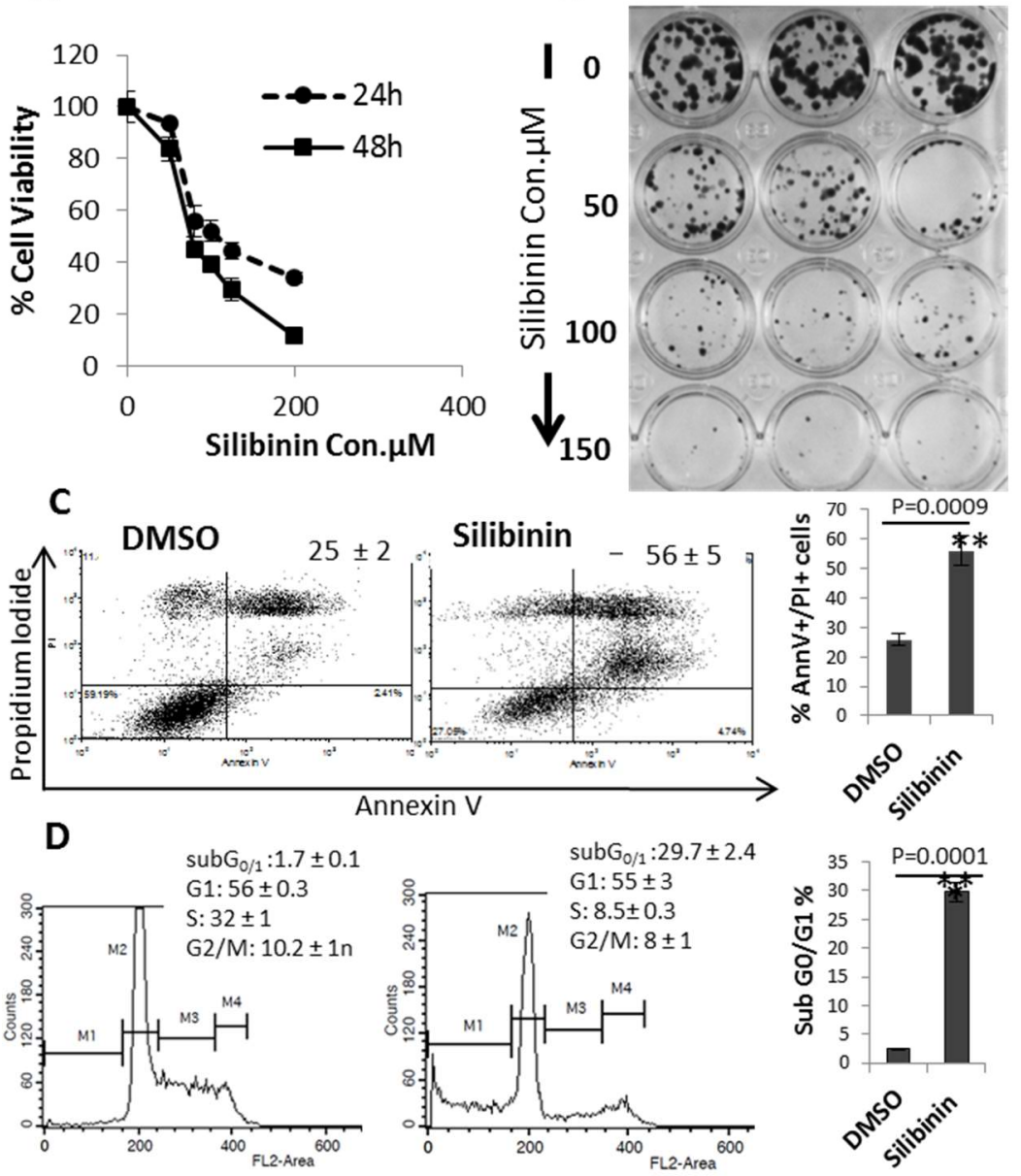

E

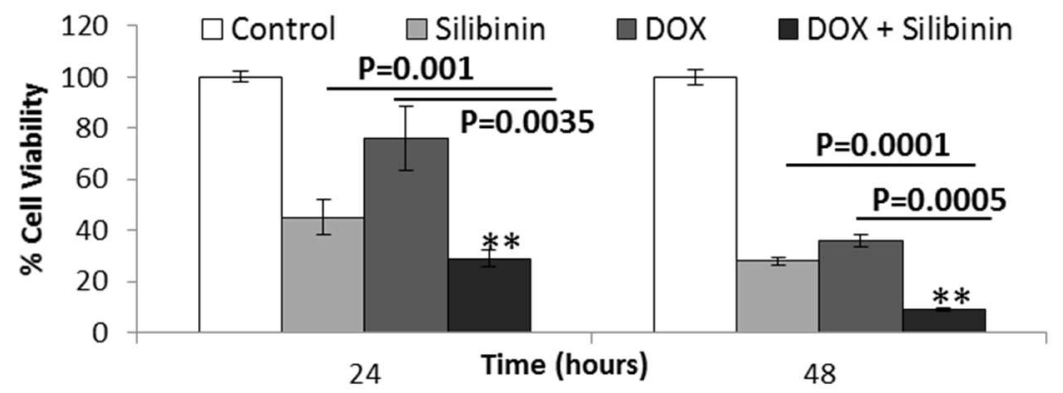

Figure 1. The effects of silibinin against B16-F10 melanoma cells.

A. Dose-response curve for the growth inhibitory effects of silibinin measured by MTT assay.

B. The anti-proliferative effects of silibinin assessed by clonogenic assay.

C. Induction of apoptosis by silibinin assessed using Annexin V/PI staining.

D. Cell cycle analysis performed using PI staining.

E. Cytotoxic effects of silibinin $(125 \mu \mathrm{M})$ and doxorubicin $(18 \mathrm{nM})$ combinational therapy measured by MTT assay.

The control is the cells treated with $2 \%$ DMSO; Values represent a mean of three experiments \pm standard deviation. 


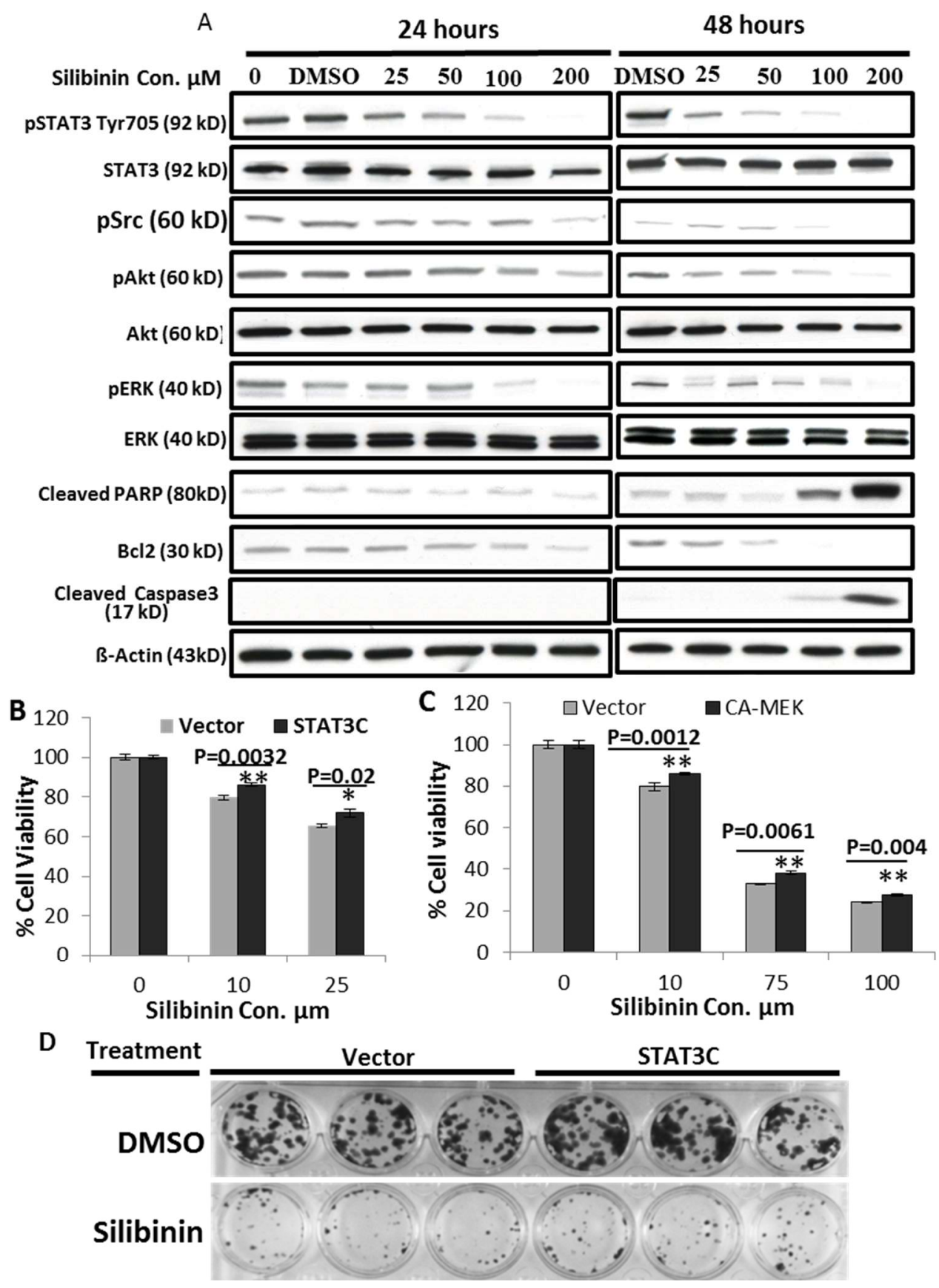

Figure 2. The effects of silibinin on oncogenic pathways in B16-F10 melanoma cells.

A. Western blot analysis of lysate from the cells treated with silibinin.

B. Growth inhibitory effects of silibinin in the cells transfected with STAT3C.

C. The effects of hyperactivate ERK (CA-MEK) on growth inhibitory effects of silibinin.

D. Anti-proliferative effects of silibinin in the cells transfected with wither STAT3C or CAMEK, assessed with clonogenic assay.

The cells were transfected with either STAT3C or CA-MEK, incubated for $24 \mathrm{hs,} \mathrm{and} \mathrm{then} \mathrm{they}$ were treated with silibinin at different concentrations. After 24 hs incubation, the cell viability was assessed by MTT. Cells were also subjected to clonogenic assay (D). These results are representative of three independent experiments. 
Figure 2D, we found a significant increase in the number of colonies in cells transfected with STAT3C prior to treatment with silibinin as compared to the control group which received vehicle only $(\mathrm{p}<0.05)$.

\section{Preparation and Characterization of polymers under study}

The PBCL- $b$-PEG- $b$-PBCL block copolymer was synthesized and characterized as reported previously by ${ }^{1} \mathrm{H}$ NMR (21). Briefly, considering a molecular weight of 1450 Da for PEG (degree of polymerization, DP, of 33 for ethylene glycol) the related peak at $3.6 \mathrm{ppm}$ was used as a reference peak. The DP of PBCL block was calculated based on the ratio of the peak at 3.6 to that at $4.1 \mathrm{ppm}$ (related to the methylene group of PBCL block (O$\left.\mathrm{CH}_{2}-\right)$ ). The calculated $\mathrm{M}_{\mathrm{n}}$ of the initial PBCL- $b-$ PEG- $b$-PBCL product was $5200 \mathrm{Da}$.

The percentage of debenzylation in the final product, i.e., PCBCL- $b$-PEG- $b$-PCBCL, was calculated using the ratio of the integration of the peak at $5.2 \mathrm{ppm}$ related to the methylene group of the benzyl substituent, to the integration of the methylene group of PCL backbone $\left(\mathrm{O}-\mathrm{CH}_{2}-\right)$ at 4.1 ppm. The ${ }^{1} \mathrm{H}$ NMR of the final product exhibited $32 \%$ debenzylation or reduction of PBCL units. The $\mathrm{M}_{\mathrm{n}}$ of PCBCL- $b$-PEG- $b$-PCBCL was $4700 \mathrm{Da}$.

The CMCs of PCBCL- $b$-PEG- $b$-PCBCL and Pluronic ${ }^{\circledR} \mathrm{F}-127$ as measured by DLS were $2.15 \pm$ 0.15 and $840 \pm 70 \mu \mathrm{g} / \mathrm{mL}$, respectively. These CMC values exhibit higher thermodynamic stability of PCBCL- $b$-PEG- $b$-PCBCL compared to Pluronic ${ }^{\circledR}$ F-127 micelles (Figure 3).

\section{Thermoresponsive transition of polymers in Tris buffer (pH 7.4)}

Sol-gel transition temperatures of the polymers under study were measured by two methods; inverse flow method and MDSC. Table 1 shows the data obtained by the inverse flow method. The PolyGel $^{\mathrm{TM}}$ prepared at 15 and $20 \mathrm{w} / \mathrm{w} \%$ concentration transformed to gel at 34 and $34.5^{\circ} \mathrm{C}$, respectively (Table 1). This observation was similar to what reported by our group before (21). On the other hand, Pluronic ${ }^{\circledR}$ F-127 made gel at 39 and $29.5^{\circ} \mathrm{C}$, at concentrations as high as 25 and $27 \mathrm{w} / \mathrm{w}$ $\%$ of the polymer, respectively. An inverse relationship was seen between Pluronic $^{\circledR}$ concentration and its sol-gel transition temperature, above $25 \% \mathrm{w} / \mathrm{w}$, as reported by previous studies
(40, 41). Under current experimental conditions, gel formation for Pluronic ${ }^{\circledR}$ F-127 was not observed at $22 \% \mathrm{w} / \mathrm{w}$ and below.

The sol-gel transition temperatures were obtained by MDSC for both polymers, as well. PolyGel $^{\mathrm{TM}}$ solution $(15 \mathrm{w} / \mathrm{w} \%)$ showed a peak at around $34.6 \pm 0.6^{\circ} \mathrm{C}$ which indicates sol-gel transition temperature (Support Data, Figure S2). This temperature is close to sol-gel temperature that is measured by inverse flow method. The sol-gel transition temperature for Pluronic ${ }^{\circledR}$ F-127 appeared at $16.3 \pm 0.7 \mathrm{C}(\mathrm{n}=3)$, which is in agreement with previous reports $(40,41)$, but lower than sol-gel transition temperatures that was obtained by inverse tube method, here.

\section{Silibinin loading and release from PolyGel ${ }^{\mathrm{TM}}$ and Pluronic F 127 hydrogel}

Silibinin loading efficiency in PolyGel ${ }^{\mathrm{TM}}$ and Pluronic ${ }^{\circledR} \mathrm{F}-127$ was $65.3 \pm 2.77$ and $90.4 \pm$ $6.18 \%$, respectively $(n=3)$. Figure 4 A shows the percentage of silibinin released from PolyGel $^{\mathrm{TM}}$ (15\%) and Pluronic ${ }^{\circledR}$ F-127 (27\%) at $37^{\circ} \mathrm{C}$ in comparison with silibinin dissolved in Tris buffer as a control. At these concentrations, the sol-gel transition temperatures for Pluronic ${ }^{\circledR} \mathrm{F}-127$ and PolyGel ${ }^{\mathrm{TM}}$ are around 27 and $34{ }^{\circ} \mathrm{C}$, respectively (Table I). Therefore, at $37^{\circ} \mathrm{C}$, both materials are expected to be in gel form, and that was the reason for the choice of this temperature in the release study. After $24 \mathrm{~h}, 98$ and $86 \%$ of silibinin, loaded in PolyGel ${ }^{\mathrm{TM}}$ and Pluronic ${ }^{\circledR}$ F-127 gel released, respectively.

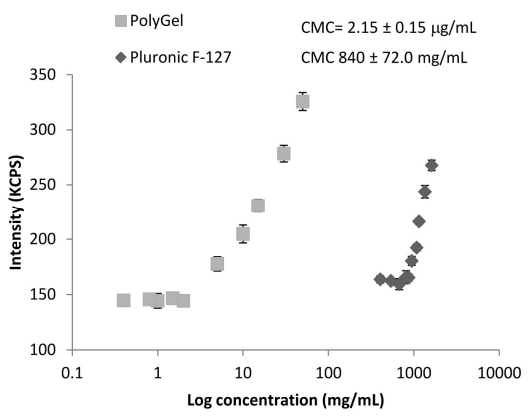

.Figure 3. Scattered light intensity (Kcps) as a function of polymer concentration $(\mu \mathrm{g} / \mathrm{mL})$ in Tris buffer $(\mathrm{pH} 7.4)$ for determination of CMC in Pluronic ${ }^{\circledR}$ F-127 and PolyGel $^{\mathrm{TM}}$ (or PCBCL- $b$-PEG- $b$-PCBCL) block copolymers. 
Both polymers significantly decreased release rate of silibinin in comparison to control in which $97 \%$ of silibinin passed the membrane at the same time point. The drug release pattern for both hydrogels was similar ( $f_{2}$ value of 52.76 ), but different from that of free drug ( $f_{2}$ values of 4.57 and 9.09 for Pluronic F-127 and PolyGel ${ }^{\mathrm{TM}}$, respectively). Both hydrogels retarded drug release by $50-60 \%$ at $6 \mathrm{~h}$. Drug release data were fitted on different kinetic models (Table 2). The best fit between release profiles of both hydrogels and kinetic models was provided by first order equation $\left(\mathrm{R}^{2}>0.998\right)$.

\section{Skin permeation study}

The permeation studies of silibinin through fullthickness mouse skin were done after applying 50 $\mu \mathrm{g} / \mathrm{mL}$ silibinin-loaded in PolyGel ${ }^{\mathrm{TM}}(15 \%)$ or in Pluronic $^{\circledR}$ F-127 (27\%) hydrogels and silibinin dissolved in Tris buffer as control. The concentration of silibinin in receptor was measured by HPLC method as mentioned above. The skin permeation test is conducted at $32{ }^{\circ} \mathrm{C}$ to mimic in vivo conditions. As it is shown in Figure $4 \mathrm{~B}$ a lag time of about 4-5 $\mathrm{h}$ was obtained for silibinin loaded in both hydrogels. After this period a constant flux of $0.80 \pm 0.087$ and $0.25 \pm 0.02 \mu \mathrm{g} . \mathrm{cm}^{-}$ ${ }^{2} \mathrm{~h}^{-1}$ for silibinin loaded in PolyGel ${ }^{\mathrm{TM}}$ and Pluronic ${ }^{\circledR}$ F-127 formulations were observed.
Silibnin permeation parameters through mouse skin is summarized in Table 3. The results indicate that silibinin loaded in PolyGel $^{\mathrm{TM}}$ provided approximately 3 folds flux, percentage of silibinin permeated after $28 \mathrm{~h}$ and drug concentration in the skin in comparison to Pluronic ${ }^{\circledR} \mathrm{F}-127$ formulation. At $32{ }^{\circ} \mathrm{C}$, Pluronic ${ }^{\circledR} \mathrm{F}-127(27 \% \mathrm{w} / \mathrm{w})$ should be in gel form, while PolyGel ${ }^{\mathrm{TM}}$ formulation $(15 \% \mathrm{w} / \mathrm{w})$ should be composed of micelles in sol form. This may partly account for higher skin permeation of silibinin in PolyGel ${ }^{\mathrm{TM}}$ compared to Pluronic ${ }^{\circledR} \mathrm{F}-127$ formulation, under study conditions (Fig 4B). However, the rapid release of silibinin from PolyGel $^{\mathrm{TM}}$ in the study cannot explain the slightly higher permeation and flux of this formulation in comparison to free drug (Table 3). For this reason, an interaction with PolyGel ${ }^{\mathrm{TM}}$ in sol form and skin was suspected, which was tested in further studies.

DSC was used for the treated skins with PolyGel $^{\mathrm{TM}}$ and Pluronic ${ }^{\circledR}$ F-127 to test this hypothesis. Results are illustrated in Table 4. Thermogram of untreated skin showed one transition around $78^{\circ} \mathrm{C}$ that was attributed to lipid structure in the skin. This peak is appeared due to melting of stratum corneum lipid (42). PolyGel ${ }^{\mathrm{TM}}$ significantly decreased this temperature and the enthalpy of this transition (Support data, Figure S3).

Table 1. Sol-gel transition temperatures of gel forming polymers under study at different concentrations, defined by inverse flow method.

\begin{tabular}{cccc}
\hline Pluronic $^{\circledR} \mathbf{F}-127$ & PolyGel $^{\text {TM }}$ & \\
\hline Concentration (\%) & Sol-gel transition temperature $\left({ }^{\circ} \mathrm{C}\right)$ & Concentration $(\%)^{\circ}$ & Sol-gel transition temperature $\left({ }^{\circ} \mathrm{C}\right)$ \\
\hline 18 & No gel formation $\left(25-60^{\circ} \mathrm{C}\right)$ & $7.5 \%$ & No gel formation $\left(25-60^{\circ} \mathrm{C}\right)$ \\
20 & No gel formation $\left(25-60^{\circ} \mathrm{C}\right)$ & $15 \%$ & $34 \pm 0.5$ \\
22 & No gel formation $\left(25-60^{\circ} \mathrm{C}\right)$ & $20 \%$ & $34.5 \pm 0.3^{\circ} \mathrm{C}$ \\
25 & $39 \pm 0.2$ & - & - \\
27 & $26.7 \pm 0.8$ & - & - \\
\hline
\end{tabular}

Table 2. Assessment of the kinetic model for the release of silibinin from PolyGel ${ }^{\mathrm{TM}}$.

\begin{tabular}{lllll}
\hline & RSQ & Slope & intercept & MPE\% \\
\hline Zero & 0.8682 & 0.0271 & 0.1352 & 795.7914 \\
first & 0.9810 & -0.0772 & -0.0435 & 566.5597 \\
Higuchi & 0.9340 & 0.1938 & -0.1178 & 392.8415 \\
pepas & 0.7366 & 1.3500 & -4.1455 & 142.9365 \\
Hixon & 0.9546 & 0.0174 & 0.0325 & 702.0215 \\
Second root of mass & 0.9367 & 0.0219 & 0.0566 & 740.9179 \\
3/2 root of mass & 0.9161 & 0.0246 & 0.0826 & 767.4835 \\
weibul & 0.8276 & 1.6581 & -4.2940 & 80.2996 \\
Linear Wagner & 0.7448 & 0.0996 & -1.5066 & 396.8242 \\
Log Wagner & 0.9463 & 1.1177 & -2.3494 & 57.6171 \\
\hline
\end{tabular}



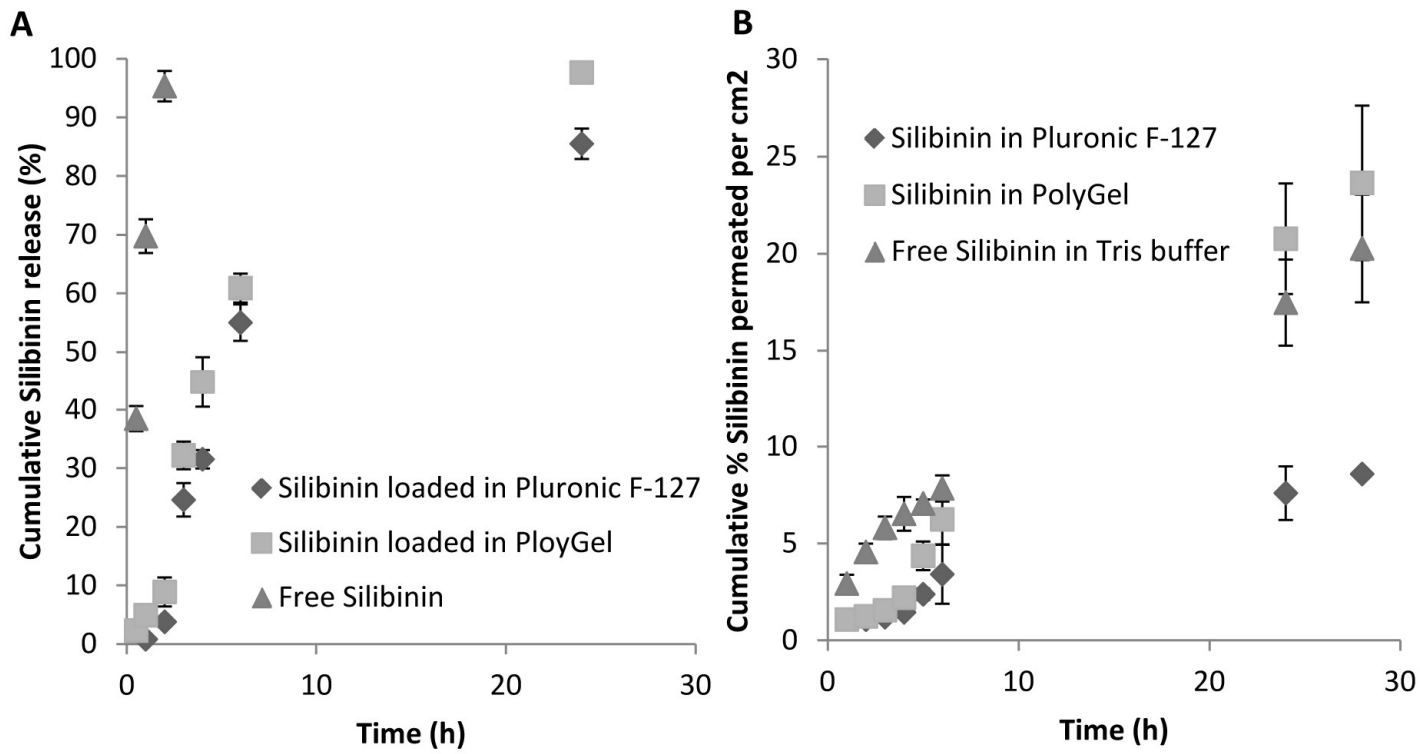

Figure 4. The release profile and skin permeation of silibinin loaded in PolyGel $^{\mathrm{TM}}$ (15\%) and Pluronic ${ }^{\circledR} \mathrm{F}-127(27 \%)$.

A. The release profile of silibinin from hydrogel formulations in Tris-buffer $(\mathrm{pH}=7.4)$ containing $0.1 \%$ tween $80(\mathrm{w} / \mathrm{v})$

B. Mouse skin transport of silibinin loaded in Pluronic ${ }^{\circledR}$ F-127 and PolyGel ${ }^{\text {TM }}$. Phosphate buffer $(\mathrm{pH}=7.0)$ was used in the Receiver compartment

Error bars show standard deviations for three independent studies

This effect was not observed for the skin treated with Pluronic ${ }^{\circledR}$ F-127.

\section{The effect of formulation on the cytotoxicity and Stat-3 inhibitory activity of silibinin}

Figure 5A and 5B depicts the effect of silibinin hydrogel formulations on the level of pSTAT3 in melanoma B16-F10 cells. The treatment of B16F10 cells with silibinin loaded in Pluronic ${ }^{\circledR}$ F-127 at $10 \mu \mathrm{M}$ resulted in $50 \%$ reduction in the percentage of pSTAT3+ cells as compared with untreated group. Silibinin $(10 \mu \mathrm{M})$ loaded in PolyGel $^{\mathrm{TM}}$ reduced the percentage of pSTAT3+ cells from $50 \%$ (untreated cells) to $34 \%$. We did not observe statistically significant differences in the percentage of pSTAT3 ${ }^{+}$cells between untreated cells and the cells treated with silibinin loaded in Pluronic ${ }^{\circledR} \mathrm{F}$ 127 or PolyGel $^{\mathrm{TM}}$ at $5 \mu \mathrm{M}$. Pluronic ${ }^{\circledR} \mathrm{F}-127$ and PolyGel $^{\mathrm{TM}}$ formulations of silibinin potently inhibited the growth of B16-F10 cells with average $\mathrm{IC}_{50} \mathrm{~S}$ of 32 and $30 \mu \mathrm{M}$, respectively (Figure $5 \mathrm{C}$ ).

\section{DISCUSSION}

In this study, silibinin was found to significantly suppresses key oncogenic pathways (i.e STAT3 and ERK) and induce apoptosis in B16-F10 melanoma cells. Thermoresponsive hydrogel formulations were also developed from Pluronic ${ }^{\circledR} \mathrm{F}-127$ and PCBCL- $b$-PEG- $b$-PCBCL copolymer $\left(\right.$ PolyGel $^{\mathrm{TM}}$ ) and evaluated for delivery of silibinin, in vitro. Our findings show PolyGel ${ }^{\mathrm{TM}}$ formulation of silibinin may offer a promising formulation for the treatment of malignant melanoma via local administration.

Silibinin potently inhibited the growth of B16 melanoma cells and induced apoptosis. These observations are in line with the results of previous studies showing silibinin induces growth inhibitory effects and apoptosis in various cancer cell lines $(43,44)$. Consistent with previous studies, we also found silibinin to significantly enhance the cytotoxic effects of doxorubicin in B16 melanoma cells (31). Correlating with our findings on the anticancer effects of silibinin in B16 melanoma 
cells, silibinin suppressed the activation of three important oncogenic pathways including STAT3, ERK and Akt. Previous studies have provided compelling evidence that STAT3, ERK, and Akt confer survival and proliferative advantages to melanoma cells $(35,45,46)$. We observed a significant reduction in the growth inhibitory effects of silibinin in B16 cells transfected with the constitutively active forms of STAT3 or ERK. Suppression of these two pathways by silibinin might be the possible mechanisms by which silibinin inhibits growth and induces apoptosis in B16 melanoma cells. In support of this notion, Lee $\mathrm{MH}$ et al have recently reported direct binding of silibinin to MEK1/2 and RSK2 resulting in reduced activation of NF- $\kappa \mathrm{B}$, activator protein-1, and STAT3 in human melanoma cell lines (43). We also observed a significant reduction in the level Bcl-2 protein, an anti-apoptotic protein, following treatment of the B16-F10 cell with silibinin. The suppression of $\mathrm{Bcl}-2$ was correlated with an increase in the level of cleaved caspase 3 which is the main effector molecule in cellular apoptosis. Elevated level of cleaved caspase 3 suggests suppression of anti-apoptotic proteins (i.e, Bcl-2) might be the mechanism by which silibinin enhances the cytotoxic effects of doxorubicin when given in combination. Suppression of Bcl-2 level is one of the important strategies used to enhance the activity of chemotherapy $(47,48)$.
Suppressive effects of silibinin on STAT3 pathway has been well documented in the literature (16). Constitutively active STAT3 is found in about $70 \%$ of human cancers and play a major role in cancer progression through modulation of the genes which regulate cancer cell growth, apoptosis, metastasis, angiogenesis, and tumor induced immunosuppression (18). A growing number of studies show that suppression of STAT3 in tumor not only induces potent direct cytotoxic effects, but exerts bystander effects through activation of antitumor immune responses (49). Therefore, suppression of STAT3 in a primary tumor locally can result in systemic anticancer effects through the activation of anti-tumor immune effector cells. Silibinin is a non-toxic compound and several publications have reported the safe administration of relatively high doses of silibinin in patients $(7,8$, $20,50,51)$. The excellent safely profile of silibinin and its potent inhibitory effects on key oncogenic pathways such as STAT3 makes this compound a very attractive anticancer agent for treatment of STAT3 hyperactive cancers, including malignant melanoma. Nevertheless, the application of silibinin in cancer patients is hampered by its low water solubility and poor bioavailability. Development of appropriate drug formulations for silibinin is an unmet need for clinical application of this compound in cancer patients.

Table 3. Silibinin permeation parameters through mouse skin $(n=3)$

\begin{tabular}{lccc}
\hline Treatment & $\begin{array}{c}\text { Cumulative silibinin\% } \\
\text { permeated in } 28 \mathrm{~h} \pm \mathrm{SD}\end{array}$ & $\begin{array}{c}\text { Steady state permeation } \\
\text { flux } \pm \mathrm{SD}(\mathrm{Jss}) \\
\left(\mu \mathrm{g} / \mathrm{cm}^{2} . \mathrm{h}\right)\end{array}$ & $\begin{array}{c}\text { silibinin concentration in skin } \pm \mathrm{SD} \\
\left(\mu \mathrm{g} / \mathrm{cm}^{2}\right)\end{array}$ \\
\hline silibinin in Tris buffer & $29.1 \pm 2.53$ & $0.44 \pm 0.062$ & $8.11 \pm 0.86$ \\
silibinin in PolyGel ${ }^{\mathrm{TM}}$ & $34.17 \pm 3.17$ & $0.80 \pm 0.087$ & $8.61 \pm 0.72$ \\
silibinin in Pluronic ${ }^{\circledR} \mathrm{F}-127$ & $11.82 \pm 1.94$ & $0.25 \pm 0.02$ & $2.93 \pm 0.26$ \\
\hline
\end{tabular}

Table 4. Transition temperature and enthalpy of untreated and hydrogel treated skin $(n=3)$

\begin{tabular}{lcc}
\hline Skin Treatment & Transition temperature $\pm \mathrm{SD}\left({ }^{\circ} \mathrm{C}\right)$ & Transition enthalpy $\pm \mathrm{SD}(\mathrm{J} / \mathrm{g})$ \\
\hline Untreated & $78.3 \pm 5.33$ & $5.01 \pm 0.45$ \\
PolyGel $^{\mathrm{TM}}$ & $64.1 \pm 3.28$ & $0.75 \pm 0.08$ \\
Pluronic ${ }^{\circledR} \mathrm{F}-127$ & $80.1 \pm 3.55$ & $3.93 \pm 0.42$ \\
\hline
\end{tabular}




\section{A}
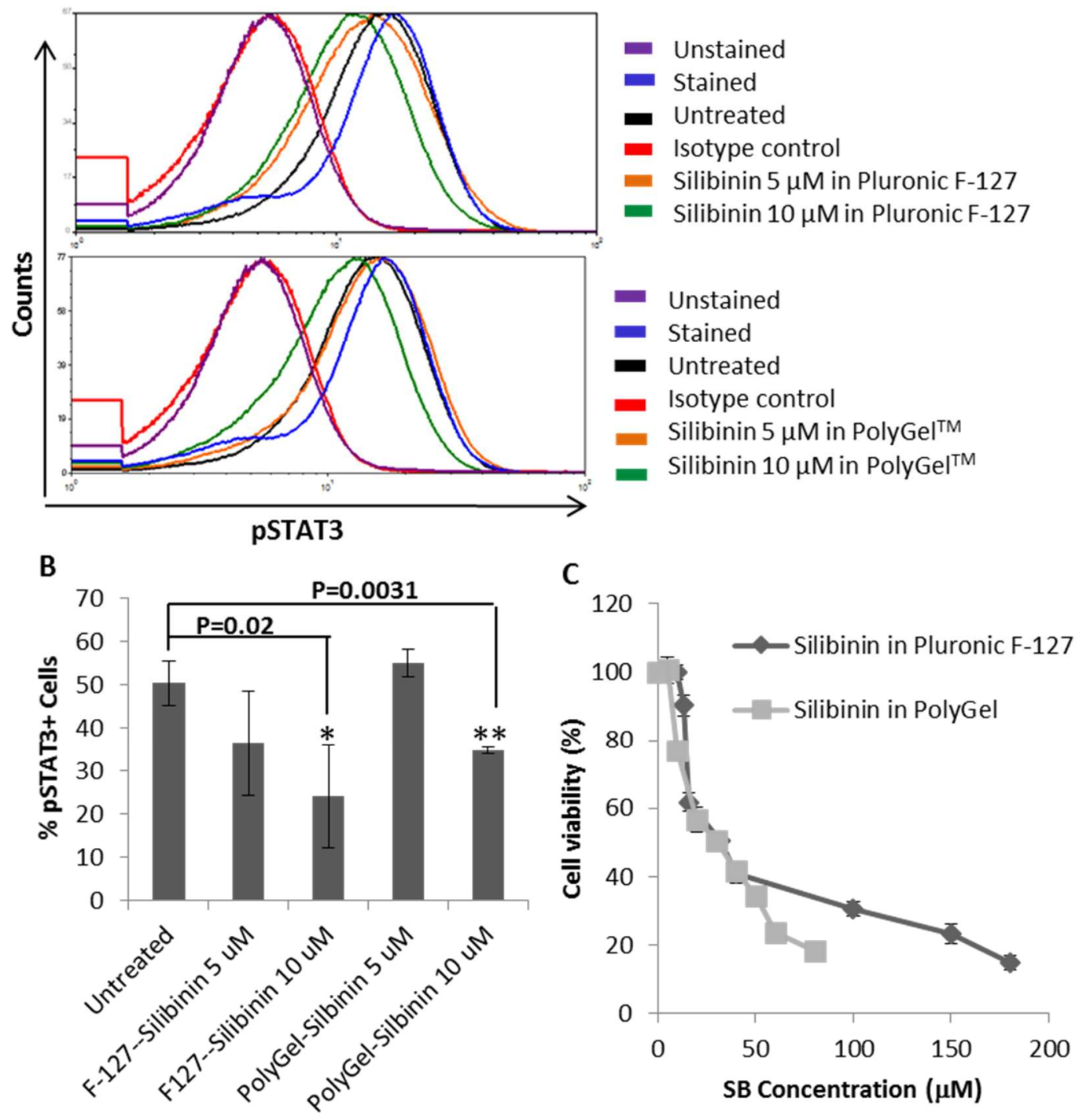

Figure 5. The effects of silibinin formulations on B16-F10 cells

A, B. Suppressive effects of hydrogels of silibinin on pSTAT3 level determined by flow cytometry.

C. Growth inhibitory effects of silibinin hydrogel formulations assessed by MTT

Here, we report on the development of a novel formulation for local delivery of silibinin. The developed formulation $\left(\right.$ PolyGel $\left.^{\mathrm{TM}}\right)$ which was based on self-associating triblock copolymers of PEG and functionalized PCL, showed better thermodynamic stability over a commercially available triblock copolymer of PEG and poly(propylene glycol), i.e., Pluronic ${ }^{\circledR}$ F-127. This was indicated by significantly lower CMC (2.15 \pm 0.15 vs $840 \pm 70 \mu \mathrm{g} / \mathrm{mL}$ ) of PolyGel ${ }^{\mathrm{TM}}$ polymers versus Pluronic ${ }^{\circledR}$ F-127. PolyGel ${ }^{\mathrm{TM}}$ incorporated a relatively high amount of silibinin, formed gel upon incubation at temperatures slightly below physiological temperature $\left(34{ }^{\circ} \mathrm{C}\right)$, and significantly retarded the release of incorporated drug under physiological conditions. The pattern of silibinin release from PolyGel ${ }^{\mathrm{TM}}$ fitted first- order release kinetics, which means that drug release was controlled by diffusion through hydrogel. Diffusion-controlled, swelling-controlled and chemical-controlled models are used to describe the release of drugs from hydrogels (52). Diffusion- 
controlled model for silibinin release from both hydrogels indicates that the diffusion of silibinin is slower than hydrogel swelling. Therefore, rate limiting step for drug release is drug diffusion. This finding is in accordance with hydrophobic property of silibinin and its low solubility in two hydrogels under study. This release pattern demonstrates that drug is uniformly dissolved or dispersed in hydrogel matrix. In this system, non-constant rate drug release is the result of the increasing diffusional resistance and decreasing area at the penetrating diffusion front.

The results of permeation studies of silibinin through full-thickness mouse skin indicates that PolyGel $^{\mathrm{TM}}$ loaded with silibinin provided approximately 3 folds flux of silibinin after $28 \mathrm{~h}$ in the skin in comparison with Pluronic ${ }^{\circledR}$ F 127. Flux of silibinin through skin from PolyGel ${ }^{\mathrm{TM}}$ was higher than that of control drug dissolved in Tris buffer. This may be partly attributed to the physical state of PolyGel $^{\mathrm{TM}}$ in sol form compared to Pluronic ${ }^{\circledR} \mathrm{F}$ 127 , which was a gel, under the conditions of the skin permeation study. We also suspected a change in the structure of skin by PolyGel ${ }^{\mathrm{TM}}$ to have contributed to slightly higher permeation of silibinin from PolyGel compared to free drug skin permeation. The relatively high flux of drug from mouse skin shows that the developed PolyGel ${ }^{\mathrm{TM}}$ formulation might be useful for topical delivery of this drug through skin in cancer treatment.

We also observed PolyGel ${ }^{\mathrm{TM}}$ to significantly decrease the temperature and enthalpy of the mouse skin transition. This effect was not observed for Pluronic ${ }^{\circledR}$ F-127. The intercellular lipids of the stratum corneum have been considered a major component of the skin barrier function (53). The intercellular lipids in the stratum corneum arrange in highly ordered lamella with a non-polar mixture that can arrange into bilayers (54). Ceramids and lipids in stratum corneum have a cylindrical molecular shape and they are able to form lamellar gel crystalline phase. Gel crystalline phases are less permeable than liquid crystalline phases (55). It seems that PolyGel ${ }^{\mathrm{TM}}$ induced more fluidity in lipid structure and because of that decreased skin resistance against silibinin permeation and penetration through the skin. This effect may partly be responsible for higher drug flux for silibinin formulation in PolyGel $^{\mathrm{TM}}$ in comparison with Pluronic $^{\circledR}$ and control (free drug). PolyGel ${ }^{\mathrm{TM}}$ decreased lipid integrity and increased silibinin diffusion through mouse skin that resulted in higher drug concentration in the skin. On the other hand, the control group which used tris buffer as its vehicle provided comparable silibinin concentration in the skin to that for PolyGel ${ }^{\mathrm{TM}}$, but lower flux. This could be due to skin hydration by the control.

Silibinin loaded in PolyGel ${ }^{\mathrm{TM}}$ was found to preserve its functional activity, which was indicated by effective inhibition of cell growth and STAT3 activity by PolyGel $^{\mathrm{TM}}$ formulation of silibinin as compared with free drug. Compared to free silibinin, PolyGel ${ }^{\mathrm{TM}}$ formulation of silibinin was found to have lower $\mathrm{IC}_{50}$ in B16 melanoma cells. The reason for this observation might be the ability of PolyGel ${ }^{\mathrm{TM}}$ formulation in providing a drug depot in the proximity of the cells and also increasing the permeability of the cell membrane leading to higher concentration of silibinin inside the cells as compared to free drug. PolyGel ${ }^{\mathrm{TM}}$ formulation of silibinin also suppressed the level of pSTAT3 in B16 melanoma cells. Given the role of STAT3 in the induction of immunosuppression in cancer patients, in situ delivery of a STAT3 inhibitor (i.e silibinin) in tumor is expected to result in systemic anticancer effects through activation of cytotoxic $\mathrm{T}$ cells specific for cancer cells. In support of this notion, we have previously reported the activation of antitumor effector cells following intratumoral administration STAT3 inhibitory molecules (56).

In conclusion, the data presented in this paper show that silibinin potently inhibit the growth of B16 melanoma cells through the suppression of key growth and survival pathways (i.e ERK and STAT3). We also developed a PCBCL $-b$-PEG- $b$ PCBCL based formulation of silibinin (PolyGel ${ }^{\mathrm{TM}}$ ) which formed thermoresponsive hydrogel at $15 \%$ concentration, demonstrated sol-gel transition temperature of $34-35^{\circ} \mathrm{C}$, and provided slower release of silibinin under physiological conditions. PolyGel $^{\mathrm{TM}}$ formulations of silibinin, potently inhibited the growth of B16-F10 melanoma cells and suppressed pSTAT3 level in these cells, which indicate that the developed formulation can provide the delivery of functional drug to cancer cells. Our in vitro and ex vivo findings suggest the promise of PolyGel $^{\mathrm{TM}}$ formulation of silibinin for its topical delivery as a useful strategy in the treatment of malignant melanoma. In future studies, this formulation may also be considered as a gelforming degradable subcutaneous depot for 
sustained silibinin delivery in the vicinity of malignant melanoma lesions.

\section{ACKNOWLEDGEMENTS}

This work was supported by a research operating grant from Natural Science and Engineering Council of Canada (NSERC) and Alberta Innovates Health Solutions (AIHS).

Behzad Sharif Makhmalzadeh and Ommoleila Molavi equally contributed to this work.

\section{CONFLICT OF INTEREST}

PolyGel $^{\mathrm{TM}}$ is licensed to Meros Polymers Inc.

\section{REFERENCES}

1. Ferenci P, Dragosics B, Dittrich H, Frank H, Benda $\mathrm{L}$, Lochs $\mathrm{H}$, et al. Randomized controlled trial of silymarin treatment in patients with cirrhosis of the liver. J Hepatol, 1989;9:105-13.

2. Meeran SM, Katiyar S, Elmets CA, Katiyar SK. Silymarin inhibits UV radiation-induced immunosuppression through augmentation of interleukin-12 in mice. Mol Cancer Ther, 2006;5:1660-8.

3. Zielinska-Przyjemska M,Wiktorowicz K. An in vitro study of the protective effect of the flavonoid silydianin against reactive oxygen species. Phytother Res, 2006;20:115-9.

4. $\mathrm{Gu} \mathrm{M}$, Singh RP, Dhanalakshmi S, Agarwal C, Agarwal R. Silibinin inhibits inflammatory and angiogenic attributes in photocarcinogenesis in SKH-1 hairless mice. Cancer Res, 2007;67:3483-91.

5. Liu W, Li Y, Zheng X, Zhang K, Du Z. Potent inhibitory effect of silibinin from milk thistle on skin inflammation stimuli by 12-O-tetradecanoylphorbol13-acetate. Food Funct, 2015;6:3712-9.

6. Svobodova A, Zdarilova A, Maliskova J, Mikulkova $\mathrm{H}$, Walterova D, Vostalova J. Attenuation of UVAinduced damage to human keratinocytes by silymarin. J Dermatol Sci, 2007;46:21-30.

7. Zhang Y, Ge Y, Chen Y, Li Q, Chen J, Dong Y, et al. Cellular and molecular mechanisms of silibinin induces cell-cycle arrest and apoptosis on HeLa cells. Cell Biochem Funct, 2012;30:243-8.

8. Ting H, Deep G, Agarwal R. Molecular mechanisms of silibinin-mediated cancer chemoprevention with major emphasis on prostate cancer. AAPS J, 2013;15:707-16.

9. Molavi O, Samadi N, Wu C, Lavasanifar A, Lai R. Silibinin suppresses NPM-ALK, potently induces apoptosis and enhances chemosensitivity in ALK- positive anaplastic large cell lymphoma. Leuk Lymphoma, 2016;57:1154-62.

10. Molavi O, Narimani F, Asiaee F, Sharifi S, Tarhriz V, Shayanfar A, et al. Silibinin sensitizes chemoresistant breast cancer cells to chemotherapy. Pharm Biol, 2017;55:729-39.

11. Bosch-Barrera J, Sais E, Canete N, Marruecos J, Cuyas E, Izquierdo A, et al. Response of brain metastasis from lung cancer patients to an oral nutraceutical product containing silibinin. Oncotarget, 2016;7:32006-14.

12. Wu K, Ning Z, Zeng J, Fan J, Zhou J, Zhang T, et al. Silibinin inhibits beta-catenin/ZEB1 signaling and suppresses bladder cancer metastasis via dualblocking epithelial-mesenchymal transition and stemness. Cell Signal, 2013;25:2625-33.

13. Singh RP, Raina K, Sharma G, Agarwal R. Silibinin inhibits established prostate tumor growth, progression, invasion, and metastasis and suppresses tumor angiogenesis and epithelial-mesenchymal transition in transgenic adenocarcinoma of the mouse prostate model mice. Clin Cancer Res, 2008;14:7773-80.

14. Raina K, Rajamanickam S, Singh RP, Deep G, Chittezhath M, Agarwal R. Stage-specific inhibitory effects and associated mechanisms of silibinin on tumor progression and metastasis in transgenic adenocarcinoma of the mouse prostate model. Cancer Res, 2008;68:6822-30.

15. Balch CM, Gershenwald JE, Soong SJ, Thompson JF, Atkins MB, Byrd DR, et al. Final version of 2009 AJCC melanoma staging and classification. J Clin Oncol, 2009;27:6199-206.

16. Bosch-Barrera J,Menendez JA. Silibinin and STAT3: A natural way of targeting transcription factors for cancer therapy. Cancer Treat Rev, 2015;41:540-6.

17. Cuyas E, Perez-Sanchez A, Micol V, Menendez JA, Bosch-Barrera J. STAT3-targeted treatment with silibinin overcomes the acquired resistance to crizotinib in ALK-rearranged lung cancer. Cell Cycle, 2016;15:3413-8.

18. Chai EZ, Shanmugam MK, Arfuso F, Dharmarajan A, Wang C, Kumar AP, et al. Targeting transcription factor STAT3 for cancer prevention and therapy. Pharmacol Ther, 2016;162:86-97.

19. Barzaghi N, Crema F, Gatti G, Pifferi G, Perucca E. Pharmacokinetic studies on IdB 1016, a silybinphosphatidylcholine complex, in healthy human subjects. Eur J Drug Metab Pharmacokinet, 1990;15:333-8.

20. Flaig TW, Gustafson DL, Su LJ, Zirrolli JA, Crighton F, Harrison GS, et al. A phase I and pharmacokinetic study of silybin-phytosome in prostate cancer patients. Invest New Drugs, 2007;25:139-46. 
21. Nikouei NS, Ghasemi N, Lavasanifar A. Temperature/pH Responsive Hydrogels Based on Poly(ethylene glycol) and Functionalized Poly(ecaprolactone) Block Copolymers for Controlled Delivery of Macromolecules. Pharm Res, 2016;33:358-66.

22. Mosmann T. Rapid colorimetric assay for cellular growth and survival: application to proliferation and cytotoxicity assays. J Immunol Methods, 1983;65:55-63.

23. Molavi O, Wang P, Zak Z, Gelebart P, Belch A, Lai $R$. Gene methylation and silencing of SOCS3 in mantle cell lymphoma. $\mathrm{Br}$ J Haematol, 2013;161:348-56.

24. Niu G, Wright KL, Huang M, Song L, Haura E, Turkson J, et al. Constitutive Stat3 activity upregulates VEGF expression and tumor angiogenesis. Oncogene, 2002;21:2000-8.

25. Lemieux E, Boucher MJ, Mongrain S, Boudreau F, Asselin C, Rivard N. Constitutive activation of the MEK/ERK pathway inhibits intestinal epithelial cell differentiation. Am J Physiol Gastrointest Liver Physiol, 2011;301:G719-30.

26. Safaei Nikouei N,Lavasanifar A. Characterization of the thermo- and $\mathrm{pH}$-responsive assembly of triblock copolymers based on poly(ethylene glycol) and functionalized poly(epsilon-caprolactone). Acta Biomater, 2011;7:3708-18.

27. Önder Topel, Burçin Acar Çakır, Leyla Budama, Hoda N. Determination of critical micelle concentration of polybutadiene-blockpoly(ethyleneoxide) diblock copolymer by fluorescence spectroscopy and dynamic light scattering. Journal of Molecular Liquids, 2013;177: 40-3.

28. Soga O, van Nostrum CF, Fens M, Rijcken CJ, Schiffelers RM, Storm G, et al. Thermosensitive and biodegradable polymeric micelles for paclitaxel delivery. J Control Release, 2005;103:341-53.

29. Sarsambi PS, Anupama K, Gudavarthi S. Development and validation of RP-HPLC method for the determination of silibinin in bulk drug and in its formulations International Journal of Institutional Pharmacy and Life Sciences 2012;2:19.

30. Moore J,Flanner H. Mathematical comparison of dissolution profiles. Pharmaceutical technology 1996;20:64-74.

31. Raina K,Agarwal R. Combinatorial strategies for cancer eradication by silibinin and cytotoxic agents: efficacy and mechanisms. Acta Pharmacol Sin, 2007;28:1466-75.

32. Tang R, Xu X, Yang W, Yu W, Hou S, Xuan Y, et al. MED27 promotes melanoma growth by targeting AKT/MAPK and NF-kappaB/iNOS signaling pathways. Cancer Lett, 2016;373:77-87.
33. Niessner H, Forschner A, Klumpp B, Honegger JB, Witte M, Bornemann A, et al. Targeting hyperactivation of the AKT survival pathway to overcome therapy resistance of melanoma brain metastases. Cancer Med, 2013;2:76-85.

34. Riverso M, Montagnani V, Stecca B. KLF4 is regulated by $\mathrm{RAS} / \mathrm{RAF} / \mathrm{MEK} / \mathrm{ERK}$ signaling through E2F1 and promotes melanoma cell growth. Oncogene, 2017;

35. Kortylewski M, Jove R, Yu H. Targeting STAT3 affects melanoma on multiple fronts. Cancer Metastasis Rev, 2005;24:315-27.

36. Bjorge JD, O'Connor TJ, Fujita DJ. Activation of human pp60c-src. Biochem Cell Biol, 1996;74:47784.

37. Irby RB,Yeatman TJ. Role of Src expression and activation in human cancer. Oncogene, 2000;19:5636-42.

38. Summy JM,Gallick GE. Src family kinases in tumor progression and metastasis. Cancer Metastasis Rev, 2003;22:337-58.

39. Kung ML, Hsieh CW, Tai MH, Weng $\mathrm{CH}$, Wu DC, $\mathrm{Wu} \mathrm{WJ}$, et al. Nanoscale characterization illustrates the cisplatin-mediated biomechanical changes of B16-F10 melanoma cells. Phys Chem Chem Phys, 2016;18:7124-31.

40. Matthew JE, Nazario YL, Roberts SC, Bhatia SR. Effect of mammalian cell culture medium on the gelation properties of Pluronic F127. Biomaterials, 2002;23:4615-9.

41. Nie S, Hsiao WL, Pan W, Yang Z. Thermoreversible Pluronic F127-based hydrogel containing liposomes for the controlled delivery of paclitaxel: in vitro drug release, cell cytotoxicity, and uptake studies. Int $\mathrm{J}$ Nanomedicine, 2011;6:151-66.

42. Shakeel F, Baboota S, Ahuja A, Ali J, Shafiq S. Skin permeation mechanism and bioavailability enhancement of celecoxib from transdermally applied nanoemulsion. J Nanobiotechnology, 2008;6:8.

43. Lee MH, Huang Z, Kim DJ, Kim SH, Kim MO, Lee SY, et al. Direct targeting of MEK1/2 and RSK2 by silybin induces cell-cycle arrest and inhibits melanoma cell growth. Cancer Prev Res (Phila), 2013;6:455-65.

44. Nakashima S, Matsuda H, Oda Y, Nakamura S, Xu F, Yoshikawa M. Melanogenesis inhibitors from the desert plant Anastatica hierochuntica in B16 melanoma cells. Bioorg Med Chem, 2010;18:233745.

45. Dhawan P, Singh AB, Ellis DL, Richmond A. Constitutive activation of $\mathrm{Akt} /$ protein kinase $\mathrm{B}$ in melanoma leads to up-regulation of nuclear factorkappaB and tumor progression. Cancer Res, 2002;62:7335-42.

46. Dhawan P,Richmond A. A novel NF-kappa Binducing kinase-MAPK signaling pathway up- 
regulates NF-kappa B activity in melanoma cells. J Biol Chem, 2002;277:7920-8.

47. Wall NR, O'Connor DS, Plescia J, Pommier Y, Altieri DC. Suppression of survivin phosphorylation on Thr34 by flavopiridol enhances tumor cell apoptosis. Cancer Res, 2003;63:230-5.

48. Zaffaroni N,Daidone MG. Survivin expression and resistance to anticancer treatments: perspectives for new therapeutic interventions. Drug Resist Updat, 2002;5:65-72.

49. Yu H, Kortylewski M, Pardoll D. Crosstalk between cancer and immune cells: role of STAT3 in the tumour microenvironment. Nat Rev Immunol, 2007;7:41-51.

50. Cheung CW, Gibbons N, Johnson DW, Nicol DL. Silibinin--a promising new treatment for cancer. Anticancer Agents Med Chem, 2010;10:186-95.

51. Mulrow C, Lawrence V, Jacobs B, Dennehy C, Sapp $\mathrm{J}$, Ramirez G, et al. Milk thistle: effects on liver disease and cirrhosis and clinical adverse effects. Evid Rep Technol Assess (Summ), 2000:1-3.

52. Lin CC,Metters AT. Hydrogels in controlled release formulations: network design and mathematical modeling. Adv Drug Deliv Rev, 2006;58:1379-408.

53. Moghimi H, Williama A, Barry B. A lamellar matrix model for stratum corneum intercellular lipids. characterization and comparison with stratum corneum intercellular structure. International Journal of Pharmaceutics 1996;131:103-15.

54. Elias PM. Epidermal lipids, barrier function, and desquamation. J Invest Dermatol, 1983;80:44s-9s.

55. Wertz PW. Lipids and barrier function of the skin. Acta Derm Venereol Suppl (Stockh), 2000;208:711.

56. Molavi O, Ma Z, Hamdy S, Lai R, Lavasanifar A, Samuel J. Synergistic antitumor effects of $\mathrm{CpG}$ oligodeoxynucleotide and STAT3 inhibitory agent JSI-124 in a mouse melanoma tumor model. Immunol Cell Biol, 2008;86:506-14. 